\title{
Heavy metal pollution of soils affected by the Guadiamar toxic flood
}

\author{
F. Cabrera*, L. Clemente, E. Díaz Barrientos, R. López, J.M. Murillo \\ Instituto de Recursos Naturales y Agrobiología de Sevilla (CSIC), Apartado 1052, 41080 Sevilla, Spain
}

Total heavy metal concentrations were determined in soil samples of seven selected areas along the Guadiamar river valley affected by the toxic flood, after removal of the deposited sludge. Mean total concentrations of nine elements (As, $\mathrm{Au}, \mathrm{Bi}, \mathrm{Cd}, \mathrm{Cu}, \mathrm{Pb}, \mathrm{Sb}, \mathrm{Tl}$ and $\mathrm{Zn}$ ) out of the 23 (As, $\mathrm{Au}, \mathrm{Ba}, \mathrm{Be}, \mathrm{Bi}, \mathrm{Cd}, \mathrm{Co}, \mathrm{Cr}, \mathrm{Cu}, \mathrm{In}, \mathrm{Mn}, \mathrm{Mo}, \mathrm{Ni}$, $\mathrm{Pb}, \mathrm{Sb}, \mathrm{Sc}, \mathrm{Sn}, \mathrm{Th}, \mathrm{Tl}, \mathrm{U}, \mathrm{V}, \mathrm{Y}$ and $\mathrm{Zn}$ ) analysed were higher in sludge-covered soils than in unaffected soils. Mean values of total $\mathrm{As}, \mathrm{Au}, \mathrm{Pb}, \mathrm{Sb}, \mathrm{Tl}$ and $\mathrm{Zn}$ in sludge-affected soils were higher than the upper limits for normal soils world-wide. Mean concentrations of $\mathrm{Bi}, \mathrm{Cd}$ and $\mathrm{Cu}$ were within these ranges, although some individual values exceeded the upper limits. In all sampling areas, severe heavy metal pollution was observed in the superficial layers $(0-20 \mathrm{~cm})$ of most of the affected soils, which decreased downward in the soil profile. Generally, in soils with more than $25 \%$ of clay, concentration of heavy metals below the $20-\mathrm{cm}$ depth decreased to values close to those of the background level of the Guadiamar valley soils, while in coarser soils, heavy metal pollution penetrated below this depth, being noticeable down to a depth of at least $50-80 \mathrm{~cm}$.

Keywords: Soil; Heavy metals; Pollution; Soil texture

\section{Introduction}

In the early hours of the 25th April 1998, a tailing-dam dike at Los Frailes open-pit pyrite mine (Aznalcóllar, $45 \mathrm{~km}$ west of Seville, Spain) was breached, allowing water and solids from the tailings pond to be discharged into the nearby Agrio river, a tributary of the Guadiamar river. Approximately 4.5 million cubic meters of slurry, composed of acidic water loaded with heavy metals and other toxic elements, finely divided metal sulphides (mainly pyrite), and materials used in the refining (floating) process, inundated both 
riverbanks of the Agrio and Guadiamar rivers and threatened the Doñana National Park, Europe's largest national park. Along $40 \mathrm{~km}$, a strip of approximately $300 \mathrm{~m}$ wide on both sides of the rivers was covered by a layer $(2-30 \mathrm{~cm}$ thick) of toxic black sludge (IGME, 1998). Approximately 4500 ha of agricultural land devoted to dry-land agriculture and fruit and olive tree orchards were affected by the pollution (Consejería de Medio Ambiente, 1998).

Dissolved and particulate heavy metals (from now on we use the term heavy metals to refer not only to those metals with density $>5 \mathrm{~g} \mathrm{~cm}^{-3}$, but also to other trace and toxic elements) in the slurry can pollute the soil. Dissolved heavy metals react with soil components (clay minerals, iron, aluminium and manganese oxides, carbonates, and organic matter) and are retained through different sorption processes (Selim and Amacher, 1997). The retention, and therefore the depth of penetration, of the dissolved heavy metals depends on the soil properties $(\mathrm{pH}$, redox potential, moisture content, bulk density, texture, and composition) (Adriano, 1986). At the same time, sludge rich in heavy metal sulphides can enter the soil through cracks and pores, increasing the total concentration of heavy metals in the soil. Sulphidic components of the sludge, exposed to atmospheric oxygen and moisture aided by bacteria (e.g. Thiobacillus thiooxidans, Thiobacillus ferrooxidans), can undergo a series of oxidation and hydrolysis reactions producing sulphuric acid and soluble and mobile metal sulphates (Förstner and Wittmann, 1983). According to Williamson and Johnson (1981), the factors liable to affect soil acidification are the carbonate:pyrite (or metal sulphide) ratio of the soil and the reactivity of the sulphidic components (which is related to the crystal form and to the particle size of the minerals).

In order to start the remediation of the affected soils, rapid information was necessary on the extent of the pollution. This paper deals with the work carried out immediately after the flood to evaluate the degree and the penetration of the heavy-metal pollution in the profiles of the affected soils.

\section{Experimental}

\subsection{Sampling areas and sites}

Between the 8th and 15th of May 1998, soil samples were taken at different depths (0-5, 5-10, $10-15,15-20$, and $20-50 \mathrm{~cm}$ ) at sampling sites in seven areas along the Guadiamar valley (Fig. 1), all of them on land devoted to extensive agriculture.

Sites S1-S4 are in the area named Finca Soberbina $(4.5 \mathrm{~km}$ from the tailing-dam), on the left bank of the Guadiamar river opposite the confluence with the Agrio river. The soil is a piedmont of the calcareous Mio-Pleistocene massif of Aljarafe, and had alluvial influence until recent times, when the river formed a new meander and left its old bed. Today, this soil is outside the river's dynamic influence. Sites $\mathrm{S} 2$ and $\mathrm{S} 4$ are approximately $200 \mathrm{~m}$ from the river bed, in the area of land covered by the sludge, and S1 and S3 some $20 \mathrm{~m}$ from $\mathrm{S} 2$ and $\mathrm{S} 3$, respectively, outside the sludge-affected area.

Site D is on the right bank, $25 \mathrm{~m}$ from the Guadiamar river bed, close to the bridge of Las Doblas (12 km from the tailing-dam) on the trunk road $\mathrm{N}-431$, on a soil covered with sludge. This soil is in the low-water river bed and received alluvial deposits during flash flood events.

Sites L1-L4 are on the right bank of the river at Cortijo los Lagares (15 $\mathrm{km}$ from the tailingdam), at 40 (L1), 80 (L2) and 150 (L3) $\mathrm{m}$ from the water course on affected land, and at $180 \mathrm{~m}$ (L4) on unaffected soil. Sites L1 and L2 are in the floodplain of the river, and sites L3 and L4 are outside the dynamic influence of the river.

Sites PA1 and PA2 are $23 \mathrm{~km}$ from the tailingdam, on the right bank of the river, $20 \mathrm{~m}$ from the river bed, on unaffected (PA1) and affected (PA2) soil. These sites are close to the old bridge (Puente de Aznalcázar) of the Aznalcázar-Pilas road.

Sites A1-A3 are $25 \mathrm{~km}$ from the tailing-dam, on the right bank of the river, 50 (A1) and 100 (A3) $\mathrm{m}$ (on sludge-covered soils) and $120 \mathrm{~m}$ (A2) (on unaffected soil) from the river bed. This series of sites was designated to Aznalcázar because of the proximity of this village. Soils at PA1, PA2 

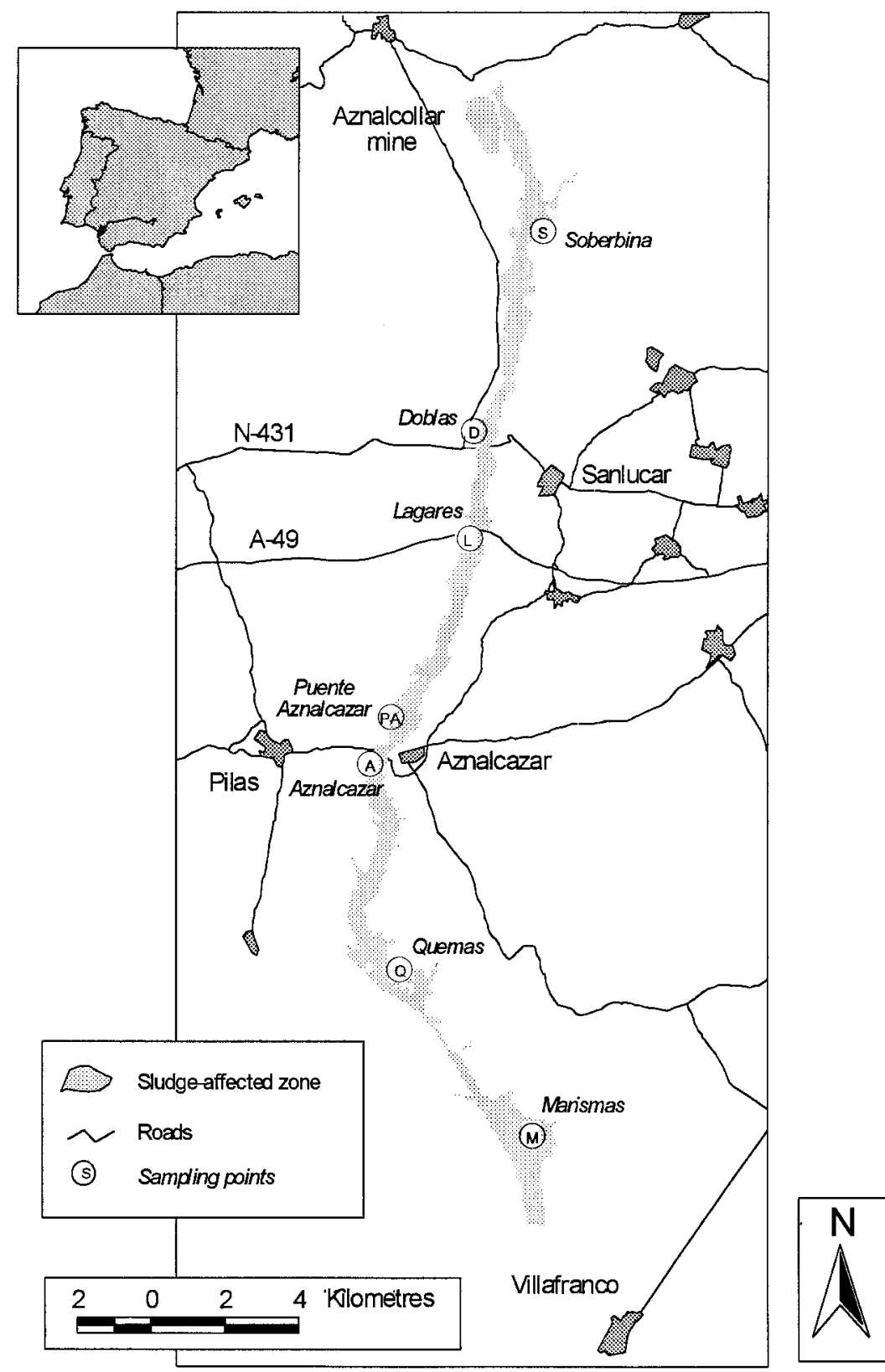

Fig. 1. The Guadiamar river. Extent of the affected zone and situation of the sampling areas. (Adapted from IGME, 1998.)

and $\mathrm{A} 1$ are in the floodplain of the river, subjected to river sedimentation, although sites PA1 and PA2 are today outside the river's influence because of the construction of a road. Soils at A2 and $\mathrm{A} 3$ are outside the dynamic influence of the river.
Site $\mathrm{Q}$ is on sludge-affected soil on the left bank of the river, $50 \mathrm{~m}$ from the river bed, at Cortijo de Quemas (30 km from the tailing-dam). Soils at this site are alluvial and are in the sedimentation meandering zone.

Sites M1-M3 (38 km from the tailing-dam) are 
on the marshes of the Guadalquivir river, across which the river flows in the last stretch of its course. This is a flat area liable to flash flooding. Here, the right bank of the river is protected with a levee to prevent flooding of the reclaimed saline soils on that bank. M1 is on the right bank, $20 \mathrm{~m}$ from the river, unaffected by the sludge, and M2 and M3 are located on the left bank, parallel to the river and $20 \mathrm{~m}$ from it, on sludge-covered land.

At sites S3, S4, A2, A3, L3 and L4, soil samples were also taken at a depth $>50 \mathrm{~cm}$.

The soils were classified as Typic Xerofluvent (D, L1, L2, PA1, PA2, A1 and Q), Vertic Xerofluvent (M2 and M3), Typic Xerochrept (A2 and A3), Calcixerollic Xerochrept (S1-S4), Typic Haploxeralf (L3 and L4) and Aquic Haploxerert (M1) (Soil Survey Staff, 1994).

\subsection{Soil sampling and analytical methods}

Sampling of the affected soils was carried out by digging a pit $50 \mathrm{~cm}$ deep after removing the deposited sludge and cleaning the surface. Whenever possible, samples of soils unaffected by the sludge were also taken in a similar way at sites close to the affected spots. Samples of sludges were also taken at each site.

Soil and sludge samples were oven-dried $\left(50^{\circ} \mathrm{C}\right)$ and crushed to pass through a $2-\mathrm{mm}$ sieve, and then ground to $<60 \mu \mathrm{m}$. Soil samples $(2 \mathrm{~mm})$ were analysed for $\mathrm{pH}$ in saturated paste (Hesse, 1971), total carbonate content was determined by the manometric method (Demolon and Leroux, 1952), and size particle distribution by the hydrometer method (Gee and Bauder, 1979).

Heavy metal and other trace element contents (As, Au, Ba, Be, Bi, Cd, Co, Cr, Cu, In, Mn, Mo, $\mathrm{Ni}, \mathrm{Pb}, \mathrm{Sb}, \mathrm{Sc}, \mathrm{Sn}, \mathrm{Th}, \mathrm{Tl}, \mathrm{U}, \mathrm{V}, \mathrm{Y}$ and $\mathrm{Zn}$ ) in the soil $(<60 \mu \mathrm{m})$ and sludge samples were determined by ICP-MS after digesting the samples with a mixture of concentrated $\mathrm{HNO}_{3}$ and $\mathrm{HF}$ to dryness and redissolving in $4 \%$ concentrated $\mathrm{HNO}_{3}$. Total heavy metal concentrations were calculated on a dry weight basis. The accuracy and precision of the method were assessed by carrying out analyses of two BCR reference samples: CRM 141 (calcareous loam soil) and CRM
277 (estuarine sediment) (Colinet et al., 1983; Griepink and Muntau, 1988). Recoveries from CRM 141 ranged from 83 to $118 \%$, with a relative standard deviation (R.S.D.) of $0.79-77 \%$, being $<10 \%$ for 18 out of the 23 elements analysed. Recoveries from CRM 277 ranged from 81 to $107 \%$, with R.S.D. of $0.54-21 \%$, being $<5 \%$ for 19 out of the 23 analysed (Table 1).

\subsection{Quantification of the soil pollution}

The degree and the penetration of heavy metal pollution in the affected soils were measured and compared using the Pollution Load Index (PLI) of Tomlinson et al. (1980). This index is based on the values of the Concentration Factors $(\mathrm{CF})$ of each metal in the soil. The $\mathrm{CF}$ is the ratio obtained by dividing the concentration of each metal in the soil $\left(C_{\text {heavy metal }}\right)$ by the base line or background value (concentration in unpolluted soil, $C_{\text {background }}$ )

$\mathrm{CF}_{i}=\frac{C_{\text {heavy metal }}}{C_{\text {background }}}$

In this paper, background values were estimated from the mean concentrations of the heavy metals in unaffected soils of the studied area.

For each sampling site, PLI at one determined soil depth may be calculated as the $n$th root of the product of the $n \mathrm{CF}$ :

$$
\mathrm{PLI}=\sqrt[n]{\left(\mathrm{CF}_{1} \times \mathrm{CF}_{2} \times \ldots \times \mathrm{CF}_{n}\right)}
$$

This index provides a simple, comparative means for assessing the level of heavy metal pollution. Values of PLI $=1$ indicate heavy metal loads close to the background level, and values above 1 indicate pollution.

\subsection{Statistical analysis}

When sets of data of total heavy metal concentrations in affected and unaffected soils were normally distributed, Student's $t$-test was used to detect differences between paired means. When the normality test failed, the Mann-Whitney 
Table 1

Analysis of BCR reference samples ${ }^{\mathrm{a}}$

\begin{tabular}{|c|c|c|c|c|c|c|c|c|c|c|}
\hline \multirow[t]{3}{*}{ Element } & \multicolumn{5}{|c|}{ CRM-141 } & \multicolumn{5}{|l|}{ CRM-277 } \\
\hline & \multicolumn{2}{|c|}{ Certified (indicative) } & \multicolumn{3}{|c|}{ Experimental } & \multicolumn{2}{|c|}{ Certified (indicative) } & \multicolumn{3}{|c|}{ Experimental } \\
\hline & Mean & R.S.D. & Mean & R.S.D. & $\begin{array}{l}\text { Recovery } \\
(\%)\end{array}$ & Mean & R.S.D. & Mean & R.S.D. & $\begin{array}{l}\text { Recovery } \\
(\%)\end{array}$ \\
\hline $\mathrm{Mn}$ & (547) & ND & 530 & 0.79 & 97 & (1600) & ND & 1560 & 0.80 & 98 \\
\hline $\mathrm{Be}$ & ND & - & 2.07 & 9.9 & - & (1.6) & ND & 1.81 & 21 & 113 \\
\hline $\mathrm{Ba}$ & ND & - & 234 & 2.2 & - & (324) & ND & 300 & 0.81 & 93 \\
\hline $\mathrm{Sc}$ & ND & - & 9.93 & 3.4 & - & 9.0 & 1.3 & 9.17 & 2.9 & 102 \\
\hline V & ND & - & 87.7 & 1.8 & - & $(102)$ & ND & 101 & 0.39 & 99 \\
\hline $\mathrm{Cr}$ & (75) & ND & 72.7 & 3.1 & 97 & 192 & 3.6 & 172 & 1.1 & 90 \\
\hline Co & (9.2) & ND & 10.9 & 4.2 & 118 & (17) & ND & 16.3 & 1.3 & 96 \\
\hline $\mathrm{Ni}$ & (30.9) & ND & 33.8 & 4.8 & 109 & 43.4 & 3.7 & 45.3 & 1.4 & 104 \\
\hline $\mathrm{Cu}$ & 32.6 & 4.3 & 34.3 & 5.5 & 106 & 101.7 & 1.6 & 105 & 0.79 & 103 \\
\hline $\mathrm{Zn}$ & 81.3 & 4.6 & 83.4 & 2.9 & 103 & 547 & 2.2 & 585 & 0.69 & 107 \\
\hline Y & ND & - & 18.1 & 1.6 & - & ND & - & 33.2 & 0.41 & - \\
\hline Mo & ND & - & 0.56 & 7.7 & - & (1.5) & ND & 1.59 & 2.1 & 106 \\
\hline As & (8) & ND & 7.68 & 1.1 & - & 47.3 & 3.4 & 42.8 & 1.4 & 90 \\
\hline $\mathrm{Cd}$ & 0.36 & 27.8 & 0.30 & 12.4 & 83 & 11.9 & 3.4 & 11.6 & 1.3 & 97 \\
\hline In & ND & - & 0.054 & 7.5 & - & ND & - & 0.32 & 11 & - \\
\hline $\mathrm{Sb}$ & ND & - & 0.84 & 36 & - & (4) & ND & 3.25 & 6.5 & 81 \\
\hline $\mathrm{Au}$ & ND & - & 0.37 & 77 & - & ND & - & 0.19 & 21 & - \\
\hline Sn & ND & - & 2.03 & 15 & - & ND & - & 7.55 & 7.0 & - \\
\hline $\mathrm{Bi}$ & ND & - & 0.58 & 11 & - & ND & - & 3.66 & 2.8 & - \\
\hline $\mathrm{Tl}$ & ND & - & 0.55 & 2.5 & - & ND & - & 1.01 & 3.0 & - \\
\hline $\mathrm{Pb}$ & 29.4 & 8.8 & 27.7 & 4.0 & 94 & 146 & 2.1 & 145 & 1.1 & 99 \\
\hline $\mathrm{U}$ & ND & - & 1.55 & 2.0 & - & (3) & ND & 2.5 & 0.54 & 83 \\
\hline Th & ND & - & 10.7 & 3.3 & - & ND & - & 8.92 & 4.6 & - \\
\hline
\end{tabular}

${ }^{\mathrm{a}} \mathrm{ND}$, not determined; R.S.D., relative standard deviation.

non-parametric test was used. A significance level of $P<0.05$ was used throughout the study. The Sigmastat (1992) analysis program of the Jandel Corporation was used for the statistical analysis.

\section{Results and discussion}

\subsection{Soil characteristics}

Table 2 shows some characteristics of the soils. The $\mathrm{pH}$ of the unaffected soils ranged from 7.0 to 7.8 , while the $\mathrm{pH}$ of the affected soils ranged from 5.8 to 7.8. Minima of the $\mathrm{pH}$ range of some samples of affected soils (S2, S4, L1, L2, A3, M2, and M3) were lower than those of the corresponding unaffected soils (S1, S2, A2, and M1). Generally, the lowest $\mathrm{pH}$ coincided with the lowest $\mathrm{CaCO}_{3}$ contents. The lowest mean values of $\mathrm{pH}$ in the studied soils were found in the sample of Las Doblas (D), which had the lowest mean values of $\mathrm{CaCO}_{3}$ and clay content.

\subsection{Heavy metal contents of soils}

Available data on the composition of the acidic water of the slurry $\left(\mathrm{pH} 5.5\right.$, As $0.27 \mathrm{mg} \mathrm{l}^{-1}, \mathrm{Cd}$ $0.85 \mathrm{mg} \mathrm{l}^{-1}, \mathrm{Cr} 0.039 \mathrm{mg} \mathrm{l}^{-1}, \mathrm{Cu} 0.021 \mathrm{mg} \mathrm{l}^{-1}, \mathrm{Hg}$ $0.008 \mathrm{mg} \mathrm{l}^{-1}$, Mn $91 \mathrm{mg} \mathrm{l}^{-1}$, Ni $1.1 \mathrm{mg} \mathrm{l}^{-1}$, Pb 3.6 $\mathrm{mg} \mathrm{1^{-1 }}, \mathrm{Zn} 462 \mathrm{mg} \mathrm{l}^{-1}$ ) (Consejería de Medio Ambiente, 1998) indicated that soils affected by the flood received large amounts of dissolved heavy metals.

Heavy metals entering the soil in particulate form can be deduced from the analysis of the sludge samples. Table 3 shows mean heavy metal concentrations and ranges in the samples of sludges covering the affected soil, compared with 
Table 2

Some characteristics of soils $(0-50 \mathrm{~cm})^{\mathrm{a}}$

\begin{tabular}{|c|c|c|c|c|c|c|c|c|c|}
\hline Sample & Longitude & Latitude & Prof. (cm) & $\mathrm{pH}$ & $\mathrm{CaCO}_{3}(\%)$ & Sand $^{\mathrm{b}}(\%)$ & $\operatorname{Silt}^{\mathrm{c}}(\%)$ & Clay $^{\mathrm{d}}(\%)$ & Mean texture \\
\hline \multicolumn{10}{|c|}{ Unaffected soils } \\
\hline S1 & W $06^{\circ} 12^{\prime} 23^{\prime \prime}$ & N $37^{\circ} 27^{\prime} 29^{\prime \prime}$ & $0-50$ & $\begin{array}{l}7.7 \\
(7.5-7.8)\end{array}$ & $\begin{array}{l}16.7 \\
(16.2-17.2)\end{array}$ & $\begin{array}{l}8.7 \\
(6.3-10.5)\end{array}$ & $\begin{array}{l}49.0 \\
(47.5-50.2)\end{array}$ & $\begin{array}{l}42.4 \\
(41.9-42.9)\end{array}$ & Silty clay \\
\hline S3 & $\mathrm{W} 06^{\circ} 12^{\prime} 25^{\prime \prime}$ & N $37^{\circ} 27^{\prime} 29^{\prime \prime}$ & $0-65$ & $\begin{array}{l}7.8 \\
(7.7-7.8)\end{array}$ & $\begin{array}{l}16.6 \\
(16.0-17.4)\end{array}$ & $\begin{array}{l}17.7 \\
(15.4-21.0)\end{array}$ & $\begin{array}{l}47.9 \\
(47.6-48.1)\end{array}$ & $\begin{array}{l}34.5 \\
(33.7-35.7)\end{array}$ & Silty clay loam \\
\hline L4 & $\mathrm{W} 06^{\circ} 13^{\prime} 58^{\prime \prime}$ & N $37^{\circ} 21^{\prime} 54^{\prime \prime}$ & $0-45$ & $\begin{array}{l}7.4 \\
(7.3-7.5)\end{array}$ & $<1$ & $\begin{array}{l}19.3 \\
(11.5-30.2)\end{array}$ & $\begin{array}{l}48.5 \\
(45.1-52.6)\end{array}$ & $\begin{array}{l}23.0 \\
(20.4-25.3)\end{array}$ & Loam \\
\hline PA1 & $\mathrm{W} 06^{\circ} 15^{\prime} 39^{\prime \prime}$ & N $37^{\circ} 18^{\prime} 21^{\prime \prime}$ & $0-50$ & $\begin{array}{l}7.4 \\
(7.0-7.5)\end{array}$ & $<1$ & $\begin{array}{l}25.3 \\
(18.7-33.2)\end{array}$ & $\begin{array}{l}38.5 \\
(33.8-43.6)\end{array}$ & $\begin{array}{l}36.2 \\
(33.1-37.4)\end{array}$ & Clay loam \\
\hline A2 & $\mathrm{W} 06^{\circ} 15^{\prime} 58^{\prime \prime}$ & $\mathrm{N} 37^{\circ} 18^{\prime} 10^{\prime \prime}$ & $0-50$ & $\begin{array}{l}7.5 \\
(7.0-7.6)\end{array}$ & $<1$ & $\begin{array}{l}24.5 \\
(22.2-27.7)\end{array}$ & $\begin{array}{l}33.6 \\
(31.7-35.5)\end{array}$ & $\begin{array}{l}41.9 \\
(41.2-42.6)\end{array}$ & Clay \\
\hline M1 & $\mathrm{W} 06^{\circ} 11^{\prime} 23^{\prime \prime}$ & N $37^{\circ} 11^{\prime} 14^{\prime \prime}$ & $0-50$ & $\begin{array}{l}7.4 \\
(7.0-7.6)\end{array}$ & $\begin{array}{l}6.8 \\
(6.3-7.8)\end{array}$ & $\begin{array}{l}4.2 \\
(3.5-5.1)\end{array}$ & $\begin{array}{l}48.5 \\
(47.9-49.7)\end{array}$ & $\begin{array}{l}47.3 \\
(46.4-48.2)\end{array}$ & Silty clay \\
\hline \multicolumn{10}{|c|}{ Affected soils } \\
\hline S2 & $\mathrm{W} 06^{\circ} 12^{\prime} 31^{\prime \prime}$ & $\mathrm{N} 37^{\circ} 27^{\prime} 30^{\prime \prime}$ & $0-50$ & $\begin{array}{l}7.6 \\
(7.3-7.8)\end{array}$ & $\begin{array}{l}17.1 \\
(15.4-18.9)\end{array}$ & $\begin{array}{l}9.7 \\
(8.1-11.8)\end{array}$ & $\begin{array}{l}44.6 \\
(41.1-46.9)\end{array}$ & $\begin{array}{l}45.8 \\
(44.9-47.1)\end{array}$ & Silty clay \\
\hline S4 & $\mathrm{W} 06^{\circ} 12^{\prime} 31^{\prime \prime}$ & N $37^{\circ} 27^{\prime} 30^{\prime \prime}$ & $0-55$ & $\begin{array}{l}7.3 \\
(7.1-7.5)\end{array}$ & $\begin{array}{l}16.6 \\
(15.7-21)\end{array}$ & $\begin{array}{l}12.1 \\
(9.2-47.3)\end{array}$ & $\begin{array}{l}49.1 \\
(47.3-52.3)\end{array}$ & $\begin{array}{l}38.7 \\
(36.3-41.3)\end{array}$ & Silty clay loam \\
\hline $\mathrm{D}$ & $\mathrm{W} 06^{\circ} 13^{\prime} 51^{\prime \prime}$ & $\mathrm{N} 37^{\circ} 23^{\prime} 00^{\prime \prime}$ & $0-50$ & $\begin{array}{l}6.9 \\
(6.3-7.2)\end{array}$ & $<1$ & $\begin{array}{l}48.4 \\
(31.5-86.3)\end{array}$ & $\begin{array}{l}33.9 \\
(9.1-46.0)\end{array}$ & $\begin{array}{l}17.8 \\
(5.5-23.2)\end{array}$ & Loam \\
\hline L1 & W $06^{\circ} 13^{\prime} 49^{\prime \prime}$ & N $37^{\circ} 21^{\prime} 47^{\prime \prime}$ & $0-50$ & $\begin{array}{l}7.4 \\
(7.0-7.7)\end{array}$ & $\begin{array}{l}14.0 \\
(12.0-15.7)\end{array}$ & $\begin{array}{l}20.2 \\
(13.5-25.4)\end{array}$ & $\begin{array}{l}49.2 \\
(46.0-53.6)\end{array}$ & $\begin{array}{l}30.6 \\
(28.9-33.2)\end{array}$ & Silty clay loam \\
\hline L2 & $\mathrm{W} 06^{\circ} 13^{\prime} 51^{\prime \prime}$ & N $37^{\circ} 21^{\prime} 51^{\prime \prime}$ & $0-50$ & $\begin{array}{l}7.3 \\
(7.0-7.6)\end{array}$ & $\begin{array}{l}14.3 \\
(12.9-16.6)\end{array}$ & $\begin{array}{l}24.5 \\
(12.5-37.8)\end{array}$ & $\begin{array}{l}48.4 \\
(42.2-52.8)\end{array}$ & $\begin{array}{l}27.1 \\
(24.8-30.3)\end{array}$ & Clay loam \\
\hline L3 & $\mathrm{W} 06^{\circ} 13^{\prime} 55^{\prime \prime}$ & $\mathrm{N} 37^{\circ} 21^{\prime} 49^{\prime \prime}$ & $0-45$ & $\begin{array}{l}7.4 \\
(7.0-7.6)\end{array}$ & $\begin{array}{l}4.6 \\
(0.0-8.1)\end{array}$ & $\begin{array}{l}23.6 \\
(18.6-31.8)\end{array}$ & $\begin{array}{l}44.5 \\
(43.2-53.3)\end{array}$ & $\begin{array}{l}27.0 \\
(25.0-28.4)\end{array}$ & Clay loam \\
\hline PA2 & $\mathrm{W} 06^{\circ} 15^{\prime} 39^{\prime \prime}$ & N $37^{\circ} 18^{\prime} 21^{\prime \prime}$ & $0-50$ & $\begin{array}{l}7.6 \\
(7.4-7.7)\end{array}$ & $\begin{array}{l}15.0 \\
(13.4-16.2)\end{array}$ & $\begin{array}{l}3.3 \\
(8.2-5.5)\end{array}$ & $\begin{array}{l}41.4 \\
(39.7-44.3)\end{array}$ & $\begin{array}{l}55.4 \\
(50.3-57.4)\end{array}$ & Silty clay \\
\hline A1 & $\mathrm{W} 06^{\circ} 15^{\prime} 58^{\prime \prime}$ & $\mathrm{N} 37^{\circ} 18^{\prime} 10^{\prime \prime}$ & $0-50$ & $\begin{array}{l}7.2 \\
(7.0-7.5)\end{array}$ & $\begin{array}{l}7.0 \\
(6.1-7.5)\end{array}$ & $\begin{array}{l}63.2 \\
(44.1-78.0)\end{array}$ & $\begin{array}{l}25.6 \\
(22.2-34.2)\end{array}$ & $\begin{array}{l}11.2 \\
(8.3-15.4)\end{array}$ & Sandy loam \\
\hline A3 & $\mathrm{W} 06^{\circ} 15^{\prime} 58^{\prime \prime}$ & $\mathrm{N} 37^{\circ} 18^{\prime} 10^{\prime \prime}$ & $0-50$ & $\begin{array}{l}7.0 \\
(6.3-7.3)\end{array}$ & $\begin{array}{l}3.3 \\
(<1-8.2)\end{array}$ & $\begin{array}{l}17.9 \\
(14.5-21.2)\end{array}$ & $\begin{array}{l}38.3 \\
(34.7-41.9)\end{array}$ & $\begin{array}{l}43.9 \\
(43.6-44.2)\end{array}$ & Clay \\
\hline Q & $\mathrm{W} 06^{\circ} 15^{\prime} 55^{\prime \prime}$ & $\mathrm{N} 37^{\circ} 14^{\prime} 47^{\prime \prime}$ & $0-40$ & $\begin{array}{l}7.2 \\
(7.0-7.4)\end{array}$ & $\begin{array}{l}6.8 \\
(6.5-7.0)\end{array}$ & $\begin{array}{l}37.9 \\
(37.4-38.4)\end{array}$ & $\begin{array}{l}35.9 \\
(34.8-36.9)\end{array}$ & $\begin{array}{l}26.3 \\
(25.0-27.6)\end{array}$ & Loam \\
\hline M2 & $\mathrm{W} 06^{\circ} 11^{\prime} 10^{\prime \prime}$ & N $37^{\circ} 11^{\prime} 15^{\prime \prime}$ & $0-50$ & $\begin{array}{l}7.0 \\
(5.8-7.5)\end{array}$ & $\begin{array}{l}7.1 \\
(0.0-9.7)\end{array}$ & $\begin{array}{l}12.2 \\
(6.6-23.2)\end{array}$ & $\begin{array}{l}50.4 \\
(43.4-60.4)\end{array}$ & $\begin{array}{l}37.4 \\
(31.4-44.0)\end{array}$ & Silty clay loam \\
\hline M3 & $\mathrm{W} 06^{\circ} 11^{\prime} 10^{\prime \prime}$ & N $37^{\circ} 11^{\prime} 15^{\prime \prime}$ & $0-50$ & $\begin{array}{l}7.5 \\
(7.0-7.7)\end{array}$ & $\begin{array}{l}12.0 \\
(10.1-13.4)\end{array}$ & $\begin{array}{l}20.2 \\
(7.3-30.2)\end{array}$ & $\begin{array}{l}54.6 \\
(49.9-63.6)\end{array}$ & $\begin{array}{l}25.4 \\
(20.1-38.3)\end{array}$ & Silt loam \\
\hline
\end{tabular}

\footnotetext{
${ }^{\mathrm{a}}$ Mean value (range).

${ }^{\mathrm{b}} 2-0.05 \mathrm{~mm}$.

${ }^{\mathrm{c}} 50-2 \mu \mathrm{m}$.

${ }^{\mathrm{d}}<2 \mu \mathrm{m}$.
} 
Table 3

Mean concentration and range $\left(\mathrm{mg} \mathrm{kg}^{-1}\right)$ of heavy metals in samples of sludge compared with normal ranges in soils

\begin{tabular}{lccc}
\hline Element & Sludge & & $\begin{array}{l}\text { Normal soil } \\
\text { range }\end{array}$ \\
\cline { 2 - 3 } & Mean & Range & \\
\hline $\mathrm{As}$ & 2878 & $1028-4022$ & $0.1-40$ \\
$\mathrm{Au}$ & 0.55 & $0.25-0.90$ & $0.01-0.02$ \\
$\mathrm{Ba}$ & 564 & $324-742$ & $10-3000$ \\
$\mathrm{Be}$ & 0.75 & $0.12-2.24$ & $0.01-40$ \\
$\mathrm{Bi}$ & 61.8 & $25.2-78.8$ & $0.1-13$ \\
$\mathrm{Cd}$ & 25.1 & $15.1-36.4$ & $0.01-2$ \\
$\mathrm{Co}$ & 43.8 & $26.2-55.4$ & $0.05-65$ \\
$\mathrm{Cr}$ & 51.7 & $29.4-67.7$ & $5-1500$ \\
$\mathrm{Cu}$ & 1555 & $715-2035$ & $2-250$ \\
$\mathrm{In}$ & 2.19 & $0.00-2.88$ & $0.7-3$ \\
$\mathrm{Mn}$ & 647 & $393-954$ & $20-10000$ \\
$\mathrm{Mo}$ & 6.77 & $2.74-8.28$ & $0.1-40$ \\
$\mathrm{Ni}$ & 15.9 & $10.1-23.2$ & $2-750$ \\
$\mathrm{~Pb}$ & 7888 & $3664-9692$ & $2-300$ \\
$\mathrm{Sb}$ & 669 & $269-797$ & $0.2-10$ \\
$\mathrm{Sc}$ & 4.66 & $2.33-9.63$ & $0.5-55$ \\
$\mathrm{Sn}$ & 14.7 & $3.02-22.6$ & $1-200$ \\
$\mathrm{Th}$ & 3.35 & $1.31-9.70$ & $1-35$ \\
$\mathrm{Tl}$ & 51.6 & $28.3-61.8$ & $0.1-0.8$ \\
$\mathrm{U}$ & 1.82 & $1.34-2.21$ & $0.7-9$ \\
$\mathrm{~V}$ & 34.8 & $19.3-48.6$ & $3-500$ \\
$\mathrm{Y}$ & 6.38 & $2.55-15.3$ & $10-250$ \\
$\mathrm{Zn}$ & 7096 & $4424-10950$ & $1-900$ \\
\hline
\end{tabular}

${ }^{\mathrm{a}}$ Bowen (1979).

normal ranges in soils (Bowen, 1979). Only nine elements (As, Au, Bi, Cd, Cu, Pb, Sb, Tl and $\mathrm{Zn}$ ) out of the 23 analysed in the sludge samples present higher concentrations than the upper limit of the normal ranges in soils. Therefore, a first assumption is that those elements could pollute the soils on which the sludge was deposited.

Mean concentrations of $\mathrm{As}, \mathrm{Au}, \mathrm{Bi}, \mathrm{Cd}, \mathrm{Cu}, \mathrm{Pb}$, $\mathrm{Sb}, \mathrm{Tl}$ and $\mathrm{Zn}$ in the $0-50-\mathrm{cm}$ layer of affected soils were higher than in unaffected soils (Table 4). Mean concentrations of $\mathrm{As}, \mathrm{Au}, \mathrm{Pb}, \mathrm{Sb}, \mathrm{Tl}$, and $\mathrm{Zn}$ in sludge-affected soils were also higher than the upper limits of the ranges of normal soils shown in Table 3 (Bowen, 1979). Mean concentration values of $\mathrm{Bi}, \mathrm{Cd}$ and $\mathrm{Cu}$ in affected soils were within the ranges of normal soils, although some individual values of these elements exceeded the upper limit of those ranges. Available data in the literature show that many of the individual values of $\mathrm{As}, \mathrm{Cd}, \mathrm{Cu}, \mathrm{Pb}$ and $\mathrm{Zn}$ con- centration in affected soils (Table 4) can be considered toxic for plant growth (Ross, 1994; Singh and Steinnes, 1994).

Table 5 shows that mean heavy metal concentrations at different depths in the $(0-50 \mathrm{~cm})$ soil layer of affected soils were higher than the corresponding values in unaffected soils. Mean concentrations of heavy metals in unaffected soils were very similar throughout the profile, while in affected soils they tended to decrease with depth. In affected soils with textures from clay loam to silty clay loam, heavy metal concentrations below the $0-50-\mathrm{cm}$ layer were similar to those in the corresponding unaffected soils. As an example, Fig. 2 shows the concentration trends of $\mathrm{Zn}$, As and $\mathrm{Tl}$ in three profiles $(0$ to $>100 \mathrm{~cm})$ of affected soils of (S4, A3 and L3) compared with those in the corresponding unaffected soils ( $\mathrm{S} 3$, A2 and L4).

To calculate the PLI values of each sampling site, the background values of the studied soils were estimated as mean concentration of $\mathrm{As}, \mathrm{Au}$, $\mathrm{Bi}, \mathrm{Cd}, \mathrm{Cu}, \mathrm{Pb}, \mathrm{Sb}, \mathrm{Tl}$ and $\mathrm{Zn}$ in unaffected soils (Table 4). Background values of $\mathrm{Cd}, \mathrm{Cu}$, and $\mathrm{Pb}$ were very close to the median for normal soils (Bowen, 1979), but those of $\mathrm{As}, \mathrm{Bi}, \mathrm{Sb}, \mathrm{Tl}$ and $\mathrm{Zn}$, were respectively $3.2,2.5,1.8,3.5$, and 1.2 times higher than the median for normal soils. As mentioned above, concentration in unaffected soils were constant throughout the profile. However, mean values in the profiles $(0-50 \mathrm{~cm})$ tended to increase downstream, especially at the last sampling site (Marismas) (Fig. 3). The same has also been reported by IGME (1998). This increase is a consequence of flash flood events, to which the river-bank soils have frequently been subjected. Waters of the Guadiamar river are characterised by high heavy metal contents, which increase in flood events, due to the transport of heavy metalrich solids precipitated upstream on the Agrio and Guadiamar river beds (Cabrera et al., 1984, 1987; Arambarri et al., 1996). For this reason, PLI mean values of unaffected soils increase downstream from 0.58 in Soberbina to 1.97 in Marismas (Fig. 3). Therefore, PLI underestimates or overestimates the heavy metal pollution level in upstream or downstream samples, respectively.

Generally, PLI values in sludge-affected soils 
Table 4

Total concentration $\left(\mathrm{mg} \mathrm{kg}^{-1}\right)$ of heavy metals in Guadiamar soils $(0-50 \mathrm{~cm})$ compared with values in normal soils and values considered toxic for plant growth

\begin{tabular}{|c|c|c|c|c|c|c|}
\hline \multirow[t]{2}{*}{ Element } & \multicolumn{2}{|c|}{ Unaffected soils } & \multicolumn{2}{|c|}{ Affected soils } & \multirow{2}{*}{$\begin{array}{l}\text { Normal } \\
\text { soils }^{\mathrm{a}} \\
\text { Median }\end{array}$} & \multirow{2}{*}{$\begin{array}{l}\text { Concentration considered } \\
\text { toxic }^{\mathrm{b}} \\
\text { Range }\end{array}$} \\
\hline & Mean & Range & Mean & Range & & \\
\hline As & 18.9 & $8.37-38.5$ & 80.4 & $9.38-1684$ & 6 & 20 \\
\hline $\mathrm{Au}$ & 0.088 & $0.035-0.27$ & 0.102 & $0.033-0.49$ & - & - \\
\hline $\mathrm{Ba}$ & 302 & $243-359$ & 289 & $214-497$ & 500 & - \\
\hline $\mathrm{Be}$ & 1.91 & $1.36-2.56$ & 1.55 & $0.55-3.67$ & 0.3 & - \\
\hline $\mathrm{Bi}$ & 0.49 & $0.24-1.17$ & 1.80 & $0.31-33.4$ & 0.2 & - \\
\hline $\mathrm{Cd}$ & 0.33 & $0.12-1.06$ & 1.69 & $0.12-22.0$ & 0.35 & $3-8$ \\
\hline Co & 12.4 & $8.19-17.6$ & 12.5 & $6.04-31.2$ & 8 & $25-50$ \\
\hline $\mathrm{Cr}$ & 68.6 & $48.3-89.7$ & 61.7 & $26.8-92.4$ & 70 & $75-100$ \\
\hline $\mathrm{Cu}$ & 30.9 & $12.3-85.0$ & 104 & $12.5-958$ & 30 & $60-125$ \\
\hline In & 0.063 & $0.034-0.11$ & 0.123 & $0.026-1.24$ & 1 & - \\
\hline $\mathrm{Mn}$ & 678 & $398-939$ & 602 & $290-940$ & 1000 & $1500-3000$ \\
\hline Mo & 0.53 & $0.33-0.99$ & 0.69 & $0.25-3.79$ & 1.2 & - \\
\hline $\mathrm{Ni}$ & 26.9 & $19.0-36.1$ & 22.9 & $8.04-39.0$ & 50 & 100 \\
\hline $\mathrm{Pb}$ & 38.2 & $19.5-86.3$ & 234 & $25.3-4969$ & 35 & $100-400$ \\
\hline $\mathrm{Sb}$ & 1.80 & $0.71-3.31$ & 13.7 & $0.89-323$ & 1 & - \\
\hline $\mathrm{Sc}$ & 12.5 & $8.89-16.7$ & 11.2 & $4.79-20.4$ & 7 & - \\
\hline Sn & 1.27 & $0.00-3.97$ & 2.29 & $0.00-11.3$ & 4 & 50 \\
\hline Th & 11.1 & $8.75-18.8$ & 9.88 & $5.39-14.7$ & 9 & - \\
\hline $\mathrm{Tl}$ & 0.70 & $0.37-2.77$ & 2.11 & $0.40-30.3$ & 0.2 & - \\
\hline $\mathrm{U}$ & 1.65 & $1.42-2.26$ & 1.65 & $1.07-2.21$ & 2 & - \\
\hline $\mathrm{V}$ & 94.4 & $69.4-120$ & 84.9 & $36.2-120$ & 90 & - \\
\hline $\mathrm{Y}$ & 17.8 & $12.4-23.9$ & 16.8 & $9.55-24.4$ & 40 & - \\
\hline $\mathrm{Zn}$ & 109 & $53.9-271$ & 487 & $56.8-5283$ & 90 & $70-400$ \\
\hline
\end{tabular}

${ }^{\mathrm{a}}$ Bowen (1979).

${ }^{\mathrm{b}}$ Ross (1994) and Singh and Steinnes (1994).

Table 5

Mean concentrations $\left(\mathrm{mg} \mathrm{kg}^{-1}\right)$ of heavy metals and values of PLI at different depths in affected and unaffected soils of the Guadiamar river valley

\begin{tabular}{lllllllllll}
\hline Depth & $\mathrm{As}$ & $\mathrm{Au}$ & $\mathrm{Bi}$ & $\mathrm{Cd}$ & $\mathrm{Cu}$ & $\mathrm{Pb}$ & $\mathrm{Sb}$ & $\mathrm{Tl}$ & $\mathrm{Zn}$ & $\mathrm{PLI}$ \\
\hline Unaffected soils & & & & & & & & & & \\
$0-5$ & 19.4 & 0.10 & 0.45 & 0.33 & 31.1 & 37.1 & 1.73 & 0.50 & 109 & 0.96 \\
$5-10$ & 18.6 & 0.12 & 0.46 & 0.34 & 30.5 & 36.8 & 1.63 & 0.61 & 110 & 1.00 \\
$10-15$ & 17.0 & 0.06 & 0.57 & - & - & 31.2 & 1.80 & 0.78 & - & - \\
$15-20$ & 18 & 0.06 & 0.54 & 0.33 & 31.1 & 39.3 & 1.97 & 1.00 & 113 & 1.02 \\
$20-50$ & 17.5 & 0.10 & 0.38 & 0.37 & 30.9 & 37.8 & 1.75 & 0.51 & 108 & 0.95 \\
& & & & & & & & & & \\
Affected soils & & & & & & & & & & \\
$0-5$ & 106 & 0.10 & 2.26 & 3.07 & 108 & 352 & 20.9 & 2.96 & 965 & 5.39 \\
$5-10$ & 172 & 0.13 & 3.64 & 2.57 & 137 & 510 & 31.8 & 3.92 & 678 & 6.73 \\
$10-15$ & 31.9 & 0.07 & 0.87 & 0.84 & 69.0 & 88.6 & 4.14 & 1.28 & 248 & 1.89 \\
$15-20$ & 37.2 & 0.11 & 1.09 & 0.95 & 81.1 & 102 & 4.75 & 1.46 & 272 & 2.26 \\
$20-50$ & 38.1 & 0.10 & 0.91 & 1.02 & 100 & 86.5 & 4.25 & 1.05 & 263 & 2.11 \\
\hline
\end{tabular}



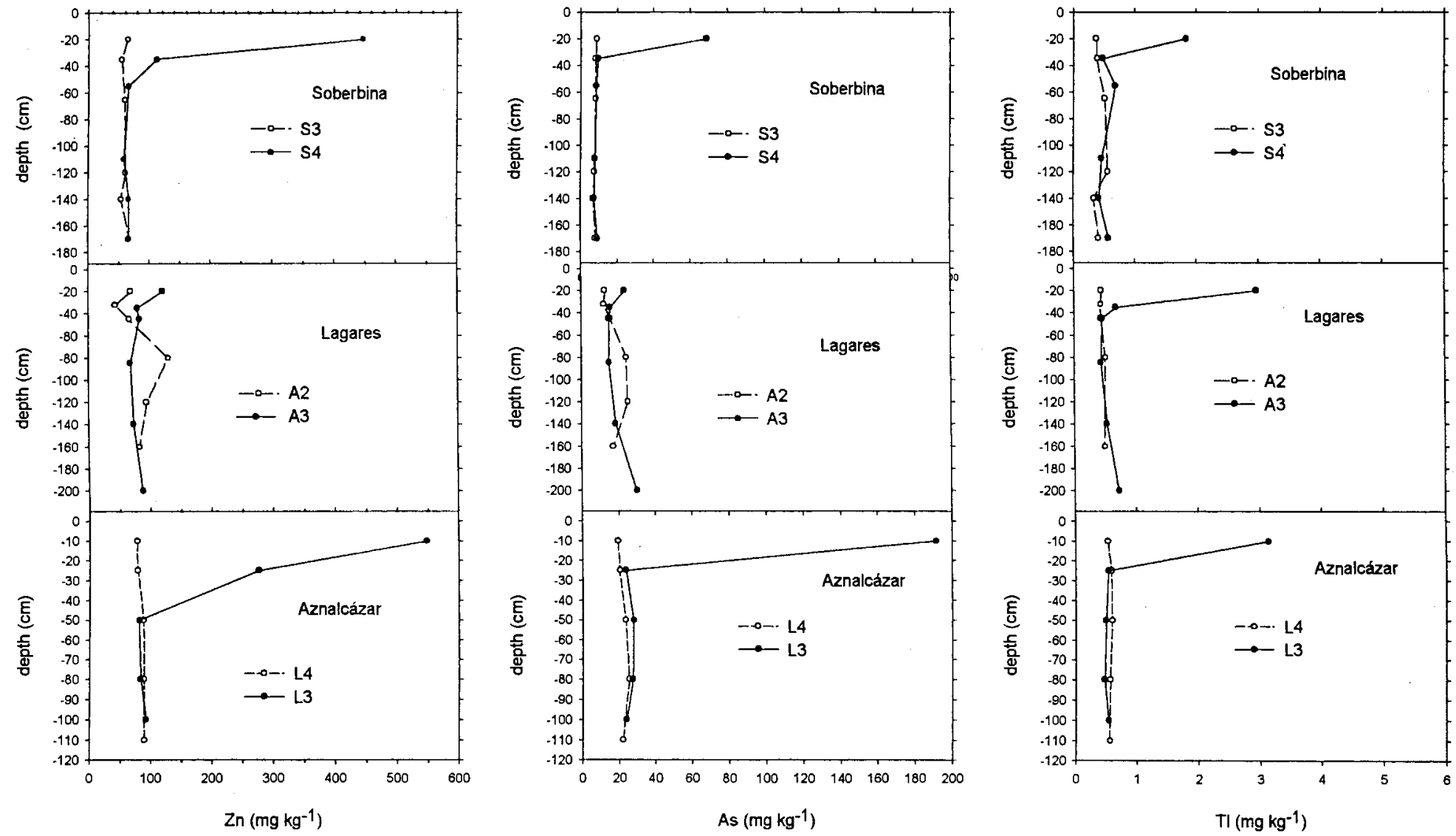

Fig. 2. Concentrations of Zn, As and $\mathrm{Tl}$ in soil profiles $(0$ to $>100 \mathrm{~cm})$. Open points: unaffected soils. Solid points: sludge-affected soils. 

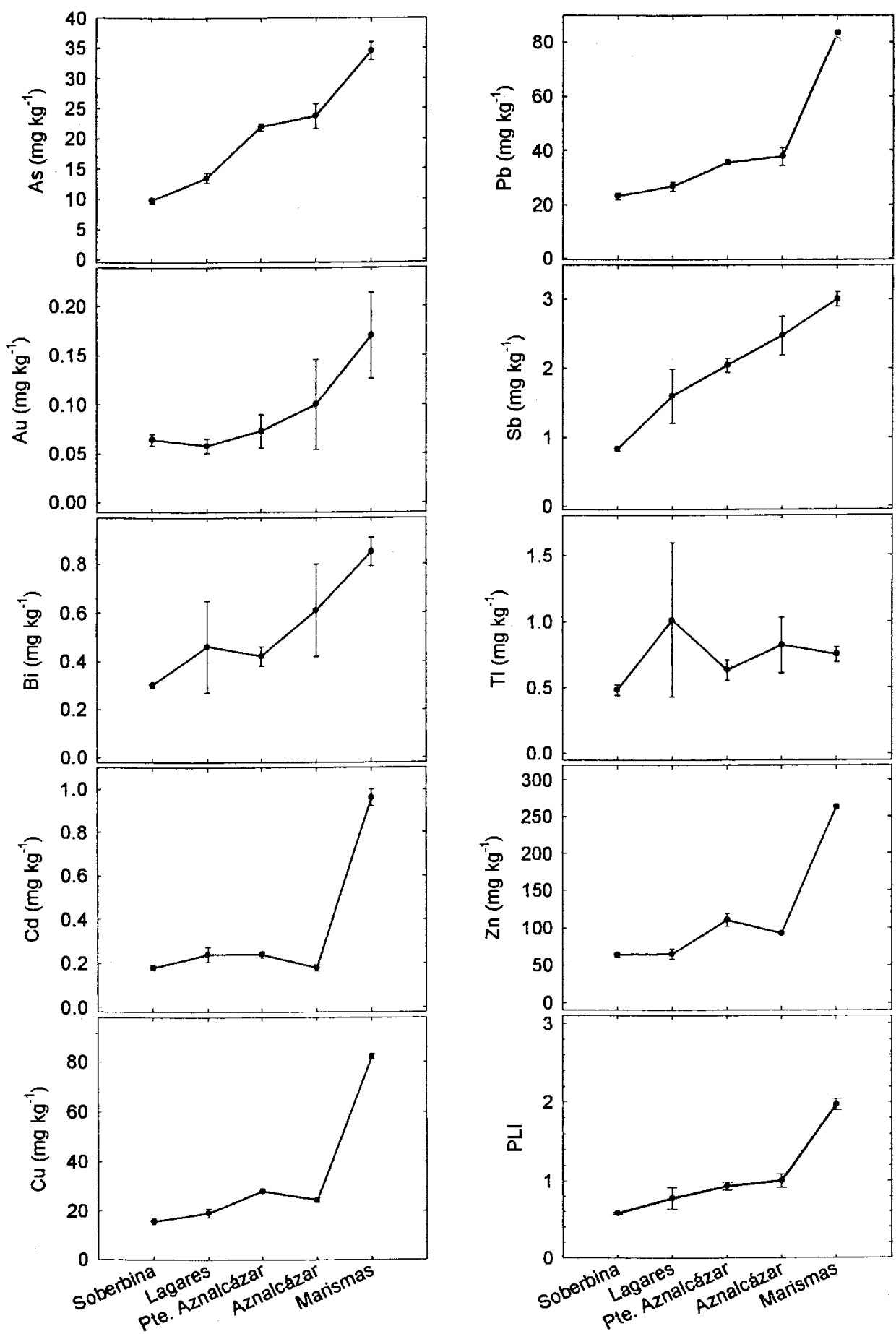

Fig. 3. Mean values of heavy metal and Pollution Load Index (PLI) in the soil profiles $(0-50 \mathrm{~cm})$ of unaffected soils along the Guadiamar River. Vertical bars are standard errors (S.E.). 
decrease downward in the profile (Fig. 4). In most of these soils, PLI values are very high in the superficial layers, indicating severe heavy metal pollution. In soils S2, S4, L1-L3, PA2, A3 and $\mathrm{M} 2$, the PLI values below the $10-20-\mathrm{cm}$ layer tended to reach the characteristic values of unaffected soils. However, in soil D between 10 and $50 \mathrm{~cm}$, and in soil A1 between 20 and $80 \mathrm{~cm}$, the PLI values still indicate heavy metal pollution. A completely different pattern was found in soil M3, in which the superficial layer was less contaminated than the deepest layer.

The clay content of soils S2, S4, L1-L3, PA2, $\mathrm{A} 3$, and M2 (open points) was higher than $25 \%$, while most of the points belonging to soils D, A1, and M3 (solid points) are below 25\% of clay (Fig. 5 ). The first group comprises soils in which heavy metals did not penetrate below $20 \mathrm{~cm}$ (Fig. 4), while the second group includes soils in which values of PLI below $20 \mathrm{~cm}$ indicate heavy metal

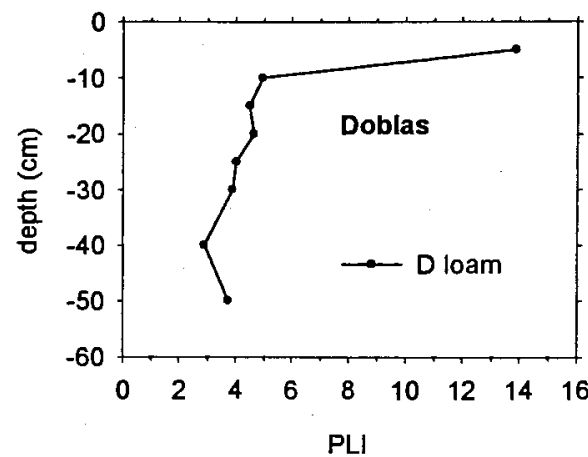

PLI
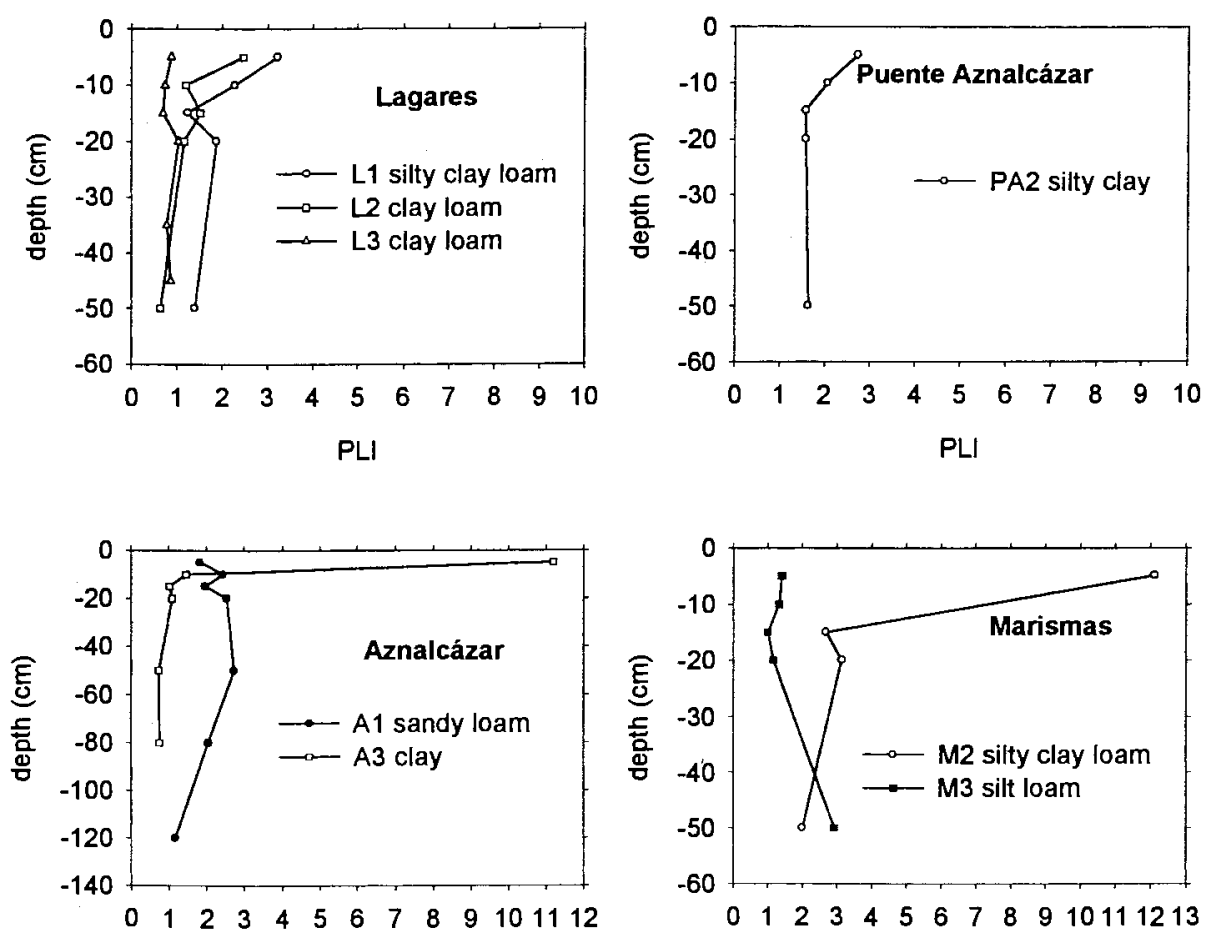

PLI

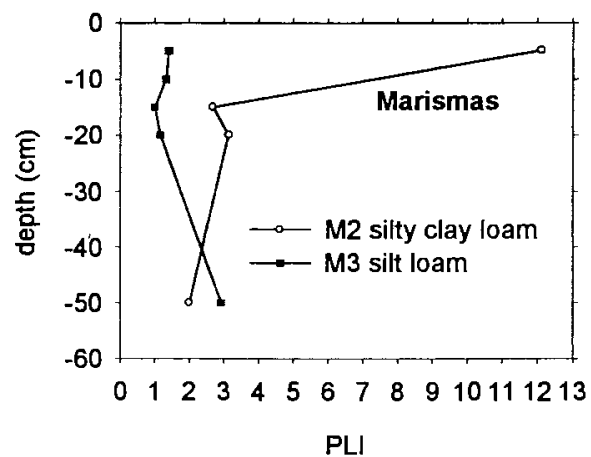

Fig. 4. Values of the Pollution Load Index (PLI) throughout the soil profile in sludge-affected soils. 


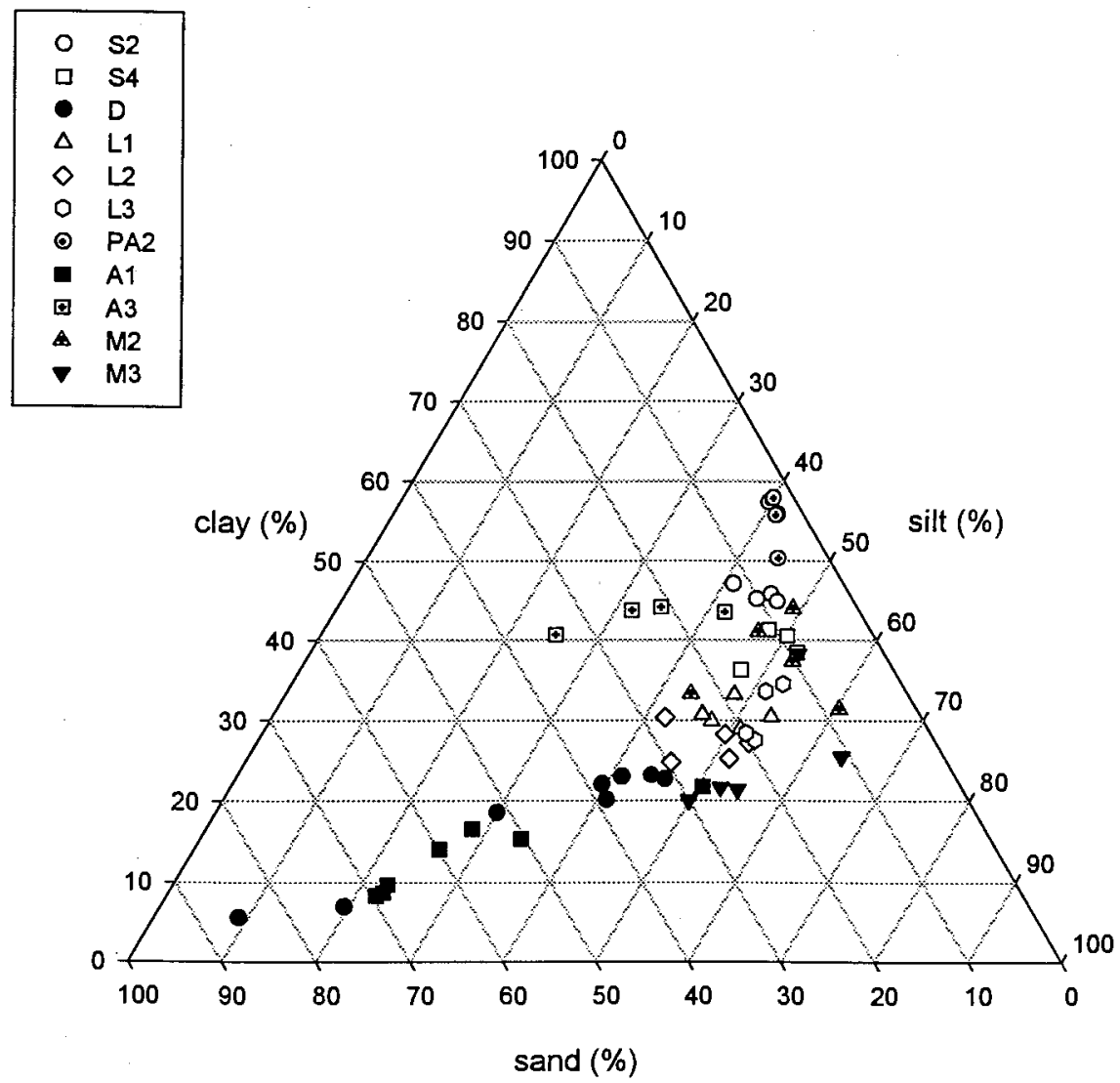

Fig. 5. Textural characteristics of sludge-affected soil samples. Open points: soils in which heavy metal pollution did not penetrate below a $20-\mathrm{cm}$ depth. Solid points: soils in which heavy metal pollution penetrated below a 20 -cm depth.

pollution. Therefore, it seems that in soils with more than $25 \%$ of clay, heavy metals did not penetrate below $20 \mathrm{~cm}$. In soil M3, in which the PLI value in the $20-50-\mathrm{cm}$ layer is higher than in the $0-20-\mathrm{cm}$ layer, the clay content of the superficial layers $(0-15 \mathrm{~cm})$ ranges from 20.1 to $25.5 \%$, while it is $25.5 \%$ at $15-20 \mathrm{~cm}$, and $38.3 \%$ at 20-50 cm (see the only two solid points in the area of open points in Fig. 5). These textural characteristics could explain the different behaviour of soil M3 regarding the penetration of heavy metals in the soil profile. It seems that in this soil, sorption of dissolved heavy metals in the slurry was the main mechanism of metal retention in the soil. Dissolved heavy metals were preferentially retained in the deeper layer, richer in clay, which is normally composed of the more reactive components of the soils.

\section{Conclusions}

The results of this study show that at all sampling sites, severe heavy metal pollution was observed in the superficial soil layers $(0-20 \mathrm{~cm})$ of most of the sludge-affected soils, and that heavy metal pollution decreased downward in the soil profile. Generally, in soils with more than $25 \%$ of clay, concentration of heavy metals below the $20-\mathrm{cm}$ depth decreased to values close to those of the background level of the Guadiamar valley soils. In coarser soils, heavy metal pollution penetrated below this depth, being noticeable down to at least $50-80 \mathrm{~cm}$.

This study shows a wide range of degrees of pollution and penetration of heavy metals in the Guadiamar river-bank soils affected by the toxic flood. Although from this study it was impossible 
to make a general recommendation for the remediation of these soils, an immediate suggestion for the 'cleaning' of the soils was to remove the layer of deposited sludge, together with the first 0-20$\mathrm{cm}$ layer of the soil. With this soil management, most of the finer-textured soils would have levels of polluting elements close to the background level of the area. A later deep ploughing $(20 \mathrm{~cm})$ would mix the soil within the ploughed depth, distributing and diluting pollutants throughout this depth. In coarser-textured soils, in which pollutants penetrated deeper, the solution would be the application of amendments (e.g. lime, iron, aluminium and manganese oxides, zeolites) to increase immobilisation of the pollutants, preventing leaching to ground water and uptake by plants. In any case, a programme of monitoring the bioavailability of pollutants in 'cleaned' soils would be an important tool to provide a warning of pollutant transfer between components of the air-water-soil-plant-animal system.

\section{Acknowledgements}

This work was carried out with the financial support of the Consejo Superior de Investigaciones Científicas. Total heavy metal concentrations were determined in the Departamento de Mineralogía y Petrografía of the Universidad de Granada. We wish to thank Dr C. Maqueda for her co-operation during the first stages of this work and Mr D. Moreno for the adaptation of the map.

\section{References}

Adriano DC. Trace elements in the terrestrial environment. New York: Springer-Verlag, 1986:533.

Arambarri P, Cabrera F, González-Quesada R. Quality evaluation of the surface waters entering the Doñana National Park (SW Spain). Sci Total Environ 1996;191:185-196.

Bowen HJM. Environmental chemistry of the elements. London: Academic Press, 1979:333.

Cabrera F, Toca CG, Díaz E, Arambarri P. Acid mine-water and agricultural pollution in a river skirting the Doñana National Park (Guadiamar river, south west Spain). Water Res 1984;18:1469-1482.
Cabrera F, Soldevilla M, Cordón R, Arambarri P. Heavy metal pollution in the Guadiamar river and the Guadalquivir estuary (south west Spain). Chemosphere 1987; 16:463-468.

Colinet E, Gonska H, Griepink B, Muntau H. The certification of the contents of cadmium, copper, mercury, lead and zinc in a calcareous loam soil. BCR Information, Report no. EUR 8833 EN. ECSC-EEC-EAEC, Brussels, 1983.

Consejería de Medio Ambiente. Junta de Andalucía. Accidente minero en Aznalcóllar y repercusiones ecológicas en el entorno de Doñana. www.cma.caan.es. Junta de Andalucía, Sevilla, 1998.

Demolon A, Leroux D. Guide pour l'etude experimental des sols. Paris: Gautier Villars, 1952:251.

Förstner U, Wittmann GTW. Metal pollution in the aquatic environment. Berlin: Springer-Verlag, 1983:486.

Gee GW, Bauder JW. Particle-size analysis hydrometer: a simplified method for routine textural analysis and a sensitive test of measurement parameters. Soil Sci Soc Am J 1979;43:1004-1007.

Griepink B, Muntau H. The certification of the contents (mass fractions) of $\mathrm{As}, \mathrm{Cd}, \mathrm{Cr}, \mathrm{Cu}, \mathrm{Hg}, \mathrm{Ni}, \mathrm{Pb}, \mathrm{Sc}, \mathrm{Se}$ and $\mathrm{Zn}$ in three sediments. BCR Information, Report no. EUR 11850 EN. ECSC-EEC-EAEC, Brussels, 1988.

Hesse PR. A textbook of soil chemical analysis. London: John Murray Publishers, 1971:520.

IGME. Contribución al establecimiento del fondo geoquímico previo a la rotura de la balsa minera de Aznalcóllar, en el aluvial del río Guadiamar (Sector Aznalcóllar-Entremuros). Instituto Tecnológico Geominero de España, Ministerio de Medio Ambiente, Madrid, 1998:31.

Ross SM. Sources and forms of potentially toxic metals in soil-plant systems. In: Ross SM, editor. Toxic metals in soil-plant system. Chichester: John Wiley \& Sons Ltd, 1994:3-25.

Selim HM, Amacher MC. Reactivity and transport of heavy metals in soils. Boca Raton, Florida: CRC Lewis Publishers, 1997:201.

Sigmastat. Statistical Software Dos. (C) Copyright Jandel Corporation, 1992.

Singh BR, Steinnes E. Soil and water contamination by heavy metals. In: Lal R, Stewart A, editors. Soil processes and water quality. Advances in soil science. Boca Raton, Florida: Lewis Publishers, 1994:233-271.

Soil Survey Staff. Keys to soil taxonomy. Soil Conservation Service, USDA, Washington, 1994:305.

Tomlinson DL, Wilson JG, Harris CR, Jeffrey DW. Problems in the assessments of heavy-metal levels in estuaries and formation of a pollution index. Helgol Meeresunters 1980;33:566-575.

Williamson A, Johnson MS. Reclamation of metalliferous mine wastes. In: Lepp NW, editor. Effect of heavy metal pollution on plants, vol. 2. Metal in the environment. Barking, Essex: Applied Science Publishers Ltd, 1981: 185-212. 